\title{
Research on College Enterprise Joint Individualized Training of English Talents Under the Background of the Belt and Road Initiative
}

\author{
Da Liu ${ }^{1}$, Qing Zhao ${ }^{1}$, Yuanyuan Chen ${ }^{1}$, Shimeng Pan $^{1}$, Yanfeng Yue ${ }^{2, \text { a }}$ \\ ${ }^{1}$ Department of Foreign Languages, Liaoning University of Science and Technology, Liaoning 114051, China \\ ${ }^{2}$ Department of International Communication, Liaoning University of Science and Technology, Liaoning \\ 114051, China \\ a50017352@qq.com
}

Keywords: The Belt and Road Initiative, coalition of schools and enterprises, English talent pattern

\begin{abstract}
As the "The Belt and Road" initiative advances constantly, the cultivation of English talents under the model of school enterprise joint training has been concerned by related scholars. Meanwhile, this is also the basic performance of cultivating excellent English talents in colleges and universities. Based on the brief introduction of "The Belt and Road", this paper analyzes the current status of personnel training, and finally puts forward some effective countermeasures for innovation of talent cultivation model.
\end{abstract}

\section{Introduction}

In recent years, the demand for professional English talents is increasing [1-2]. Therefore, the work of cultivating English talents under the background of The Belt and Road Initiative has the basic task of colleges and universities [3]. At the same time, it is also the driving force for promoting the continuous coalition of schools and enterprises. The topic in this paper is of certain educational and practical significance, which can also provide an effective reference for the relevant colleges and universities.

\section{Basic introduction of "The Belt and Road Initiative"}

As China's economy speeds up, economic and trade activities of various countries are becoming more and more frequent. The facilitation of this strategy poses higher requirements for language communication. Once the dialogue and communication are blocked due to language obstacles, the implementation of the core strategy "Full connection" would get trapped. Therefore, it's quite critical to break resistance in language communication [4]. From another angle, this strategy provides an opportunity for the training of English talents. Therefore, as a training base for talents, colleges and universities should constantly innovate the mode of talent training, implement the joint work of schools and enterprises, so as to meet the needs of market for professional English talents [5].

\section{Current situation of cultivating English talents jointly by school and enterprise}

At present, China's schools and enterprises jointly formulate talent training goal through cooperation. There are four commonly used training modes, as shown in Table 1.

Under the mode of school-enterprise cooperation, students can participate in business practice, business translation, logistic service, secretarial and so on. The proportion of project practice is shown in Table 2.

According to the data in the table, making students clearly aware of future work can provide adequate training opportunities for students, which can also offer correct guidance to those who are going to work in other fields and the logistics work. In this case, students can avoid the waste of best practice time, or missing the best practice opportunity. 
Table 1 Classification of talent training mode

\begin{tabular}{ll}
\hline Types & Content \\
\hline Order type & $\begin{array}{l}\text { The enterprise puts forward the needs for talents, and the university } \\
\text { organizes school-running patterns according to the agreement } \\
\text { "2+1"Pdents acquire theoretical knowledge for two years in the school and } \\
\text { have one year of business practice in the enterprise. }\end{array}$ \\
$\begin{array}{l}\text { "Dual-system"pattern } \\
\text { "Dlternative pattern } \\
\text { work and study }\end{array}$ & $\begin{array}{l}\text { Students alternatively acquire theoretical knowledge and summarize } \\
\text { practice experience }\end{array}$ \\
\hline
\end{tabular}

Table 2 Proportion of students' project practice

\begin{tabular}{lc}
\hline Item & Proportion \\
\hline Business practice & $21.28 \%$ \\
Business translation & $53.65 \%$ \\
Logistic service & $6.45 \%$ \\
Secretary & $15.23 \%$ \\
Others & $3.39 \%$ \\
\hline
\end{tabular}

Some students will cherish the opportunity of practice and realize their inadequacies when participating in the practical activities jointly held by the school and enterprise. 29 interns were interviewed at random to understand the students' cognition and feeling in practice, as shown in Table 3.

Table 3 Students' cognition and feeling in practice

\begin{tabular}{lc}
\hline Cognition and feeling & Quantity \\
\hline Lack of professional knowledge & 10 \\
Weak knowledge application ability & 15 \\
Weak interpersonal ability & 19 \\
Inadequate flexibility & 13 \\
\hline
\end{tabular}

As can be seen from the data analysis, there is still room for progress in consolidating theoretical knowledge and improving practical ability when school and enterprise jointly cultivate English majors. Therefore, universities and enterprises should jointly develop reasonable talent training programs, so as to improve the comprehensive ability of English majors.

\section{Strategies for the innovation of English talents training mode}

\subsection{Formulate talent training objective}

Pinpointing the goal of English talent training and formulating a reasonable training program can help to facilitate the all-round development of students. The average ranking of language skills should be understood before setting up a talent training goal, as shown in Table 4 .

Table 4 Average ranking of language skills

\begin{tabular}{cc}
\hline Language skills categories & Average ranking \\
\hline Translation skills & 3.68 \\
Writing ability & 3.82 \\
Reading ability & 3.32 \\
Listening & 2.29 \\
Oral language & 1.89 \\
\hline
\end{tabular}

Schools and enterprises shall adhere to the principle of balanced development of language skills when jointly formulating talent training programs. Moreover, they shall avoid the imbalance in the development of skills, which can not only improve the quality of teaching, but also promote the overall progress of students, thus satisfying the need of The Belt and Road strategy for English talent training. 


\subsection{Innovate the mode of school enterprise cooperation}

Students believe that the school enterprise cooperation mode needs to be improved and perfected in the process of base practice. The final survey summarizes students' evaluation of universities and internship bases, as shown in Table 5.

Table 5 Students' evaluation of universities and internship bases

\begin{tabular}{lc}
\hline Concept of evaluation & Student proportion (\%) \\
\hline Universities have light awareness of off-campus & 35 \\
internship & 21 \\
$\begin{array}{l}\text { Lack of stability in the practice base } \\
\text { Limited funds provided by colleges and } \\
\text { universities }\end{array}$ & 38 \\
\hline
\end{tabular}

According to the data introduction, the existing school enterprise joint model can not give full play to the guiding role, which can pose a negative impact on the training of English talents. Therefore, universities and enterprises should strengthen contacts and communication, jointly work out new cooperative modes and innovate talents training programs, so as to better meet students' professional needs. For example, experienced enterprise employees can personally participate in and guide the curriculum setting and assist in arranging curriculum time. Professional teachers lead students to practice base, propose and analyze problems from perspective of students, so as to help students solve the problems encountered in practice. At the same time, universities and enterprises should jointly formulate the incentive mechanism. They shall timely encourage students with good performance in the model of school enterprise cooperation and provide tutorship for poorly performed students. After applying the new model of school enterprise cooperation, the self-evaluation and the proportion of English majors are shown in Table 6.

Table 6 Self-evaluation and the proportion of English Majors

\begin{tabular}{lc}
\hline Self-evaluation content & Proportion (\%) \\
\hline Greatly improved translation level & 96 \\
Enhanced English writing ability & 95.6 \\
Sharpened reading comprehension ability & 94 \\
Improved English listening and speaking ability & 97.3 \\
\hline
\end{tabular}

It can be seen from the data analysis that the comprehensive ability of English Majors under the guidance of the model of school enterprise cooperation has been improved greatly, and their improvement space of professional learning has expanded accordingly.

\section{Conclusions}

All in all, the application of school-enterprise training mode of English talents under the background of "The Belt and Road" initiative not only meets the need of teaching in colleges and universities, but also enhances the relationship between universities and enterprises. This mode is favorable to promoting the all-round development of English majors. In addition, this mode can provide more employment opportunities for English majors, thus facilitating the implementation of "The Belt and Road" strategies.

\section{Acknowledgements}

This work was supported by 2017 Education and Reform Project of Liaoning University of Science and Technology: The Research of “Internet+Manager” Individualized Teaching Mode of University XJGYB201703;2017 Education and Reform Project of Liaoning University of Science and Technology: The Situation and Strategy of the Cultural Issues of English Cross-cultural Course under the International Background,XJGYB201748;The Research Project of the Degree and Postgraduate Students Education in China: The System Construction and Practice of the Course with 
the Aim of Cultivating the Independent Innovation Capability of Postgraduate Students Project code: 2015Y0502-021.

\section{References}

[1] Raub S, Liao H. Doing the right thing without being told: joint effects of initiative climate and general self-efficacy on employee proactive customer service performance. [J]. Journal of Applied Psychology, 2012, 97(3):651.

[2] Agarwal S. Restructuring seaside tourism: the resort lifecycle. [J]. Annals of Tourism Research, 2002, 29(1):25-55.

[3] Thoonen E E J, Sleegers P J C, Oort F J, et al. How to Improve Teaching Practices: The Role of Teacher Motivation, Organizational Factors, and Leadership Practices. [J]. Educational Administration Quarterly, 2011, 47(3):496-536.

[4] Hemmeter M L, Ostrosky M, Fox L. Social and Emotional Foundations for Early Learning: A Conceptual Model for Intervention. [J]. School Psychology Review, 2006, 35(4):583-601.

[5] Zhang Q F, Donaldson J A. The Rise of Agrarian Capitalism with Chinese Characteristics: Agricultural Modernization, Agribusiness and Collective Land Rights[J]. China Journal, 2008, 60(60):25-47. 